\title{
OPEN Author Correction: Suppression of glioblastoma by a drug cocktail reprogramming tumor cells into neuronal like cells
}

\author{
Longfei Gao, Shichao Huang, Hong Zhang, Wei Hua, Shunmei Xin, Lin Cheng®, \\ Wuqiang Guan, Yongchun Yu, Ying Mao \& Gang Pei
}

Correction to: Scientific Reports https://doi.org/10.1038/s41598-019-39852-5, published online 05 March 2019

In the Supplementary Information file originally published with this Article, an error was made during the assembly of Figure S1. In this figure, immunostaining was performed to show that serum cultured GBM cells were negative for neural progenitor markers NESTIN and SOX2 (Figure S1B), and also negative for neuronal markers such as NEUROD1 and DCX (Figure S1C). The authors noticed that the representative image showing NESTIN and SOX2 staining on serum cultured cells in Figure S1B was identical to the image showing NEUROD1 and DCX staining on GBM-3 cells in Figure S1C in the initial file. After carefully checking the original data, the authors realized that the image in Figure S1B is correct, whereas the Figure S1C in the initial file was incorrect owing to erroneous assembly.

This error has been corrected in the Supplementary Information that now accompanies the Article.

(c) (i) Open Access This article is licensed under a Creative Commons Attribution 4.0 International License, which permits use, sharing, adaptation, distribution and reproduction in any medium or format, as long as you give appropriate credit to the original author(s) and the source, provide a link to the Creative Commons license, and indicate if changes were made. The images or other third party material in this article are included in the article's Creative Commons license, unless indicated otherwise in a credit line to the material. If material is not included in the article's Creative Commons license and your intended use is not permitted by statutory regulation or exceeds the permitted use, you will need to obtain permission directly from the copyright holder. To view a copy of this license, visit http://creativecommons.org/licenses/by/4.0/.

(C) The Author(s) 2020 